\title{
Monetary Policy in Argentina Under Convertibility, 1991-96
}

\author{
Política monetária na Argentina \\ sob conversibilidade, 1991-96
}

ALDO A. ARNAUDO ***;***;

RESUMO: Uma estrutura conceitual para analisar a política monetária pode ser a relação “instrumento monetário alvo-monetário operacional da política”. Embora o critério das autoridades monetárias seja severamente restrito, essa análise também é aplicável à Argentina desde 1991. Seu regime monetário é regido pela Lei da Conversibilidade, que exige que o Banco Central converta a moeda doméstica em dólares e pela Carta do Banco Central, que prescreve que “sua missão fundamental [...] é manter o valor da moeda”. Foram encontrados cinco períodos em que as metas operacionais e os instrumentos monetários eram diferentes, enquanto o objetivo da política de estabilidade de preços permaneceu inalterado. PALAVRAS-CHAVE: Política monetária; convertibilidade; regimes cambiais; crise cambial.

ABSTRACT: A conceptual framework to analyze monetary policy might be the relationship “policy goal-operating target-monetary instrument." Although the discretion of the monetary authorities is severely restricted, this analysis is also applicable to Argentina since 1991. Its monetary regime is governed by the Convertibility Law, which requires the Central Bank to convert the domestic currency into dollars, and by the Central Bank Charter, which prescribes that its "fundamental mission $[. .$.$] is [. .$.$] to maintain the value of the currency." Five$ periods were found when the operating targets and monetary instruments were different, while the policy goal of price stability remained unchanged.

KEYWORDS: Monetary policy; convertibility; exchange rate regimes; currency crisis. JEL Classification: E52; F31.

\footnotetext{
* Profesor emérito de la Facultad de Ciencias Económicas de la Universidad Nacional de Córdoba.

** Comments by J. Piekarz, J. Uriarte, E. Folcini and anonymous referees are duly appreciated. The usual disclaimer is in order. The same for the editing by G. Arnaudo.

$* * *$ Note: tables and figures are based on official data; when the latter are revised, the last figure may not be included. Statistical data will be provided to the interested reader on request.
} 


\section{INTRODUCTION}

It is well known that monetary authorities (Central Banks) are usually made responsible for the fulfillment of policy goals (namely, economic activity, employment, price stability, etc.). These policy goals are in practice translated and evaluated in terms of specific operating targets (i.e. monetary aggregates, free reserves of the banking system, interest rates, financial credit, etc.), which in turn are attained through the control of monetary instruments (i.e. open market operations, bank reserve coefficients, etc.) (Brunner, 1969; Friedman, 1975). This "goal-operating target-instrument" monetary policy framework will be used in the foregoing analysis ${ }^{1}$.

Monetary policy may be either: (a) discretionary, if the monetary authorities are free to choose goals, operating targets and instruments; (b) subject to rules, if their decisions are constrained by a set of restrictions; or (c) tied to one and simple rule, as in currency and quasi-currency boards (Bennett, 1994).

In Argentina, two legal prescriptions, the Convertibility Act (Law n. 23.928) and the Central Bank Charter (Law n. 24.144), subject monetary authorities to a system like $\mathrm{c}^{2}$. A fixed nominal exchange rate rule (a special case of system b) gives the monetary authorities a great deal of discretionary action as long as they are not pressed to modify its value. Furthermore, in the case of currency boards, the nominal exchange rate is fixed to make the system operative.

This paper is organized as follows: section 2 contains a detailed explanation of the way the above mentioned conceptual monetary framework has worked in Argentina since the beginning of the so-called Convertibility Plan in May 1991. However, the change in economic conditions as time passed gave rise to different periods which are analyzed in sections 3, 4, 5, 6 and 7. Finally, section 8 contains a brief summary. The Appendix includes quarterly figures of the principal macrovariables, as a brief view of what was going on in the economy.

\section{CONCEPTUAL FRAMEWORK}

The goals of the monetary authority in Argentina are precisely determined by two pieces of legislation. The first legal prescription, i.e. the Convertibility Law, sets up the unconditional convertibility of the domestic currency (peso) notes and coins

\footnotetext{
1 A digression. A recent publication (Valores de la sociedad industrial, 1994) reports the personal experiences of Central Bank presidents (chief managers of the Argentine monetary policy) since mid-1970. One may conclude that the questions posed (i.e. the problems they considered they have to cope with, and the main worries they had) are at variance with those an independent observer may think. The gap between the facts and the ex-post rationalizations made by monetary economists seems quite large.

${ }^{2}$ There are some contradictions between the provisions of both mandates, although until now conflicts have not appeared.
} 
into dollars at a fixed rate ( 1 dollar $=1$ peso $)$, and instructs the Central Bank to redeem dollars at that rate. Similarly, it allows the Central Bank to purchase foreign currency at market prices. The law also prescribes that ten percent of international reserves may be held in government dollar denominated bonds valued at market prices.

The second prescription, i.e. the Central Bank Charter, states that "the primary and fundamental mission of the Central Bank of the Republic of Argentina is to maintain the value of the currency, " which supposedly means price stability. In sum, convertibility of the domestic currency and price stability are the goals of the monetary authority.

Even though the convertibility of the currency potentially subsists, the monetary authorities are not indifferent to the level of international reserves. If it is either growing or fluctuating moderately around a stable level, no problem exists; however, if it decreases substantially, the authorities start to worry. In fact, they worry not because in theory the convertibility is in danger, but instead because reserves will tend finally to disappear, throwing doubts about the consistency of the policies followed. In this case the economy will experience a phenomenon similar to the loss of reserves followed by a speculative attack described in Krugman's (1979) famous article. Therefore, the operating target to maintain the convertibility of the currency is an either stable or increasing level of international reserves.

Despite the fact that no monetary authority has direct command over domestic prices, it has the ability to affect prices indirectly modifying monetary aggregates since there is a close link between the price level and monetary variables. One common assumption is the existence of a connection between monetary aggregates and the monetary base (M0); in such a case, a simple quantitative rule says that in the long run price stability will be obtained only if the monetary base remains stable ${ }^{3}$.

Nevertheless, that assumption generally does not hold because other monetary aggregates (M1, M2, etc.), closely related to the price level, do not show a definite relationship with the monetary base. Moreover, the monetary authority may alter this relationship by the use of deposit reserve requirements for the financial system. The operating target of the monetary authorities to attain price stability consists of the whole aggregate of monetary assets: it has direct control over the monetary base and indirect over the remaining part.

In addition, the monetary authority can use another operating target, the shortterm nominal interest rate, to modify the just mentioned quantitative rules on the monetary aggregates. Interest rates might influence domestic prices, since increases in nominal interest rates frequently give rise to expectations of higher prices. Therefore, price stability is enhanced by stable nominal interest rates.

\footnotetext{
${ }^{3}$ Monetary base stability does not necessarily imply immutability: its values might be adjusted according to prevailing economic conditions.
} 
Policy instruments could be aimed to the monetary base (open market operations, purchases-sales of foreign currency and government debt, etc.), to the monetary aggregates (bank reserves coefficients) or to the nominal interest rates for Central Bank operations.

\section{FIRST PERIOD: MAY 1991-JANUARY 1993}

The implementation of a quantitative rule for monetary aggregates does not make much sense when the domestic price level is driven by variables other than monetary aggregates. Therefore, the characteristics of this period were a fixed exchange rate used as a monetary anchor, a balanced government budget (fiscal stability), and a positive shift in the demand for $\mathrm{M} 1 * 4$ (re-monetization) after the hyperinflationary shocks of 1989-90. M1*, time deposits in pesos and in dollars, and prices can be viewed in figure 1 .

Figure 1a: Monetization \& Dollarization

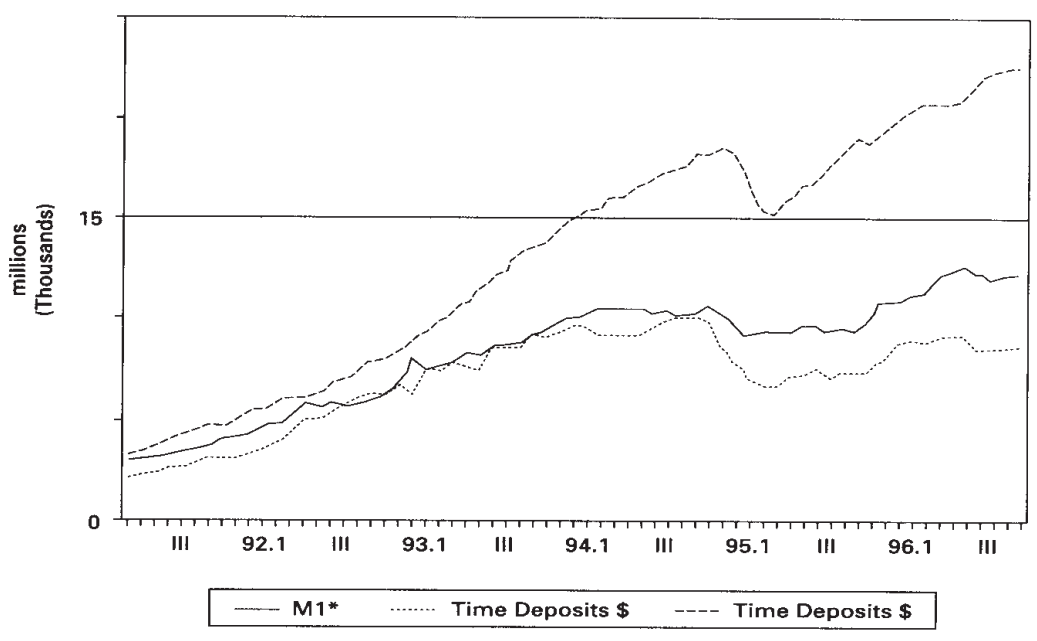

${ }^{4}$ An alternative definition of M1 (M1*) includes savings deposits (other than fixed time deposits) because they are used by most of the people as demand deposits. In February 1993 this fact was fully acknowledged by the monetary authorities when reserve coefficients for savings deposits were set equal to those of demand deposits. 


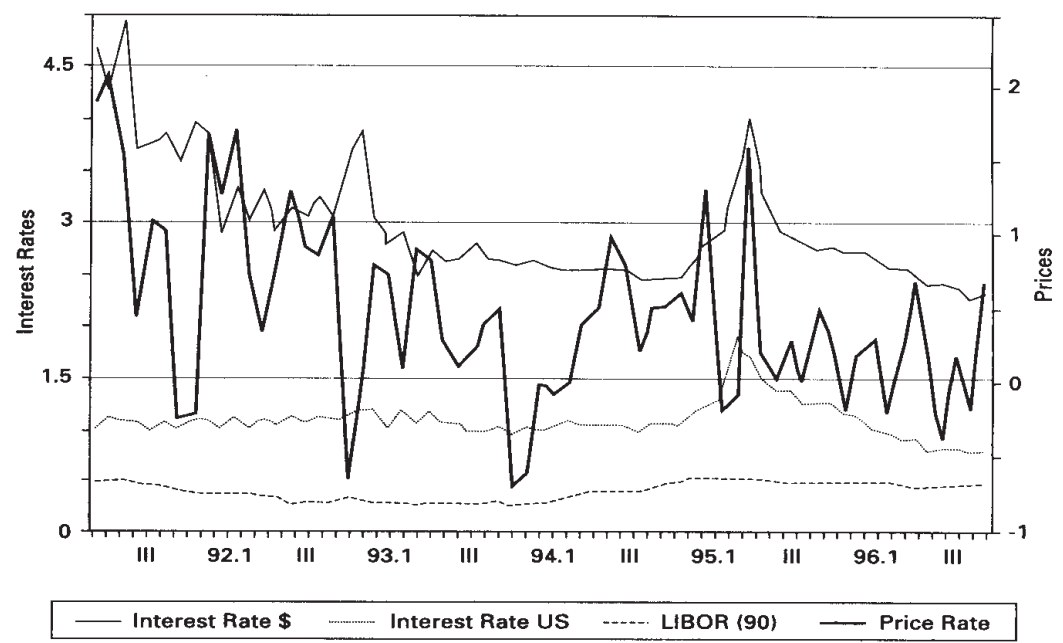

Given this context, the authorities of the Central Bank reasonably thought that an increase in the monetary aggregates was compatible with price stability as long as the economy gradually regained the past ("normal") relationship between M1" and GNP - even to a greater ratio when prices stabilize - and that the shift in demand would persist during a rather long period of time.

The loan interest rate prevailing in the domestic market was mainly determined by the deposit interest rate, which in turn was very sensitive to the overnight rate (or "call rate") applied to loans between financial institutions. These inter-financial operations take place to avoid the costs of not satisfying legal reserve requirements with the Central Bank ${ }^{5}$.

The Central Bank can influence the call rate by arranging "swaps" (in the monetary authorities' terminology, "pases activos") ${ }^{6}$, with banks and other financial institutions. A swap is a financial transaction in which one party (i.e. the Central Bank) lends funds (called "a purchase") to a counterpart (i.e. a bank), usually for a short period of time and a given interest. These operations are self-canceling in the sense that every purchase has to be followed a few days later by a "sale" for the same amount, thus the net value being zero ${ }^{7}$. Since the Central Bank might set

\footnotetext{
${ }^{5}$ Other connections between the call rate and the costs of not fulfilling required reserves are discussed by Bernanke \& Blinder (1992).

${ }^{6}$ Swaps may be considered a kind of open market operations if the monetary authorities do not want to modify permanently the monetary base, e.g. financing government budget deficits, changing the amount of International reserves, etc. This seems to be the present practice in the United States and other developed countries (Batten et al., 1990).

${ }^{7}$ The Central Bank carries out these operations with funds not allocated to redeem domestic currency (initial endowments, interests earned, foreign indebtedness, etc.).
} 
the swap interest rate at a level below the call rate, it would create a downward pressure on the second rate.

Swap operations (also called Central Bank interventions) can be carried out in foreign or domestic currency, although only the latter are considered here ${ }^{8}$. Central Bank interventions need to satisfy three requirements: (a) there must be a (implicit) decision by the monetary authority; (b) they may either be grouped or take place within a unique period of time; (c) the call rate must have reached a level substantially higher than that existing in the previous period. Since the Central Bank generally does not intervene on a daily basis, it is therefore possible to separate periods of intervention from periods of non-intervention.

A qualitative analysis of Central Bank interventions and call rates clearly shows a close relationship between the two variables. Requirements $\mathrm{b}$ and $\mathrm{c}$ are fulfilled when looking at the length of the interventions and the call and swap interest rates (columns 1, 2 and 3 of table 1, respectively). As for the requirement a, it would be very difficult to find an explicit disclosure by the monetary authority since this kind of decisions are usually made in secrecy. However, looking at the actual behavior of the Central Bank, it turns out that the probability of intervention was higher than 0.5 when the call rate rises beyond a $20 \%$ annual rate.

Table 1: Lengths of Central Bank Intervention and Non-intervention Periods, Call and Swap Interest Rates, and Amount of Swap Operations (simple averages)

\begin{tabular}{ccccc}
\hline Length & \multicolumn{2}{c}{$\begin{array}{c}\text { Interest Rates } \\
(\%, \text { annual) }\end{array}$} & $\begin{array}{c}\text { Amount } \\
\text { (average per day) } \\
\text { (million \$) }\end{array}$ \\
Intervention & $\begin{array}{c}\text { Call } \\
(1)\end{array}$ & $\begin{array}{c}\text { Swap } \\
\text { (d) }\end{array}$ & (4) \\
\hline No & 19.3 & 16.7 & 19.9 & 29.6 \\
Yes & 13.6 & 19.1 & & \\
\hline
\end{tabular}

Similar to the case of the discount window, the Central Bank might set the interest rate or the amount of the intervention. In the first instance, the volume of swaps is determined by the financial institutions, while in the latter the swap rate becomes determined by the financial institutions, in general after a bidding process. The first procedure was adopted in Argentina. When the intervention is successful, the call rate decreases, financial institutions no longer need liquid funds (except for those provided by the Central Bank) and the monetary authorities achieved the operating target (market interest rates). In 10 instances, out of the 13 interventions that took place, the call rate was more than 10 to $100 \%$ higher than that prevailing in the previous period of non-intervention.

Under the assumption that the reaction of the Central Bank is remarkably quick

\footnotetext{
${ }^{8}$ If swap operations in foreign currency arc to influence the call rate, there should be a strong correlation between both variables. However, the correlation coefficients are practically nil, implying that swaps in foreign currency are aimed to a target different than the call rate
} 
during the period of intervention, one would expect that the swap rate is positively related to the call rate ${ }^{9}$ and to the rate of inflation, which in fact experienced a persistent reduction during the period under analysis. A minor influence can be attributed to the difference between the call rate in the intervention period and the call rate in the previous non-intervention period given Central Bank prudence.

These hypotheses about the swap rate (endogenous variable) were tested statistically under a linear form, where the call interest rate, the inflation rate, and the difference between the actual and the previous call rates stand for the exogenous variables. The regression coefficient of the call rate was statistically significant, lower than one, and very important for the explanation of the dependent variable ${ }^{10}$. If one takes the call rate and the inflation rate together, the sum of their regression coefficients is close to 1 . Finally, negative coefficients for the difference between the actual and past call rates can be interpreted as cautious decisions by the monetary authorities.

When the swap rate is set by the Central Bank, the volume of operations is determined by the financial institutions themselves. This volume is negatively related to the level of the swap rate, as with prices in a demand curve, and positively related to the differential between the swap and call rates, as with income in a demand curve. A statistical test shows that taken individually neither variable has its own weight, yet they are statistically significant when taken together.

The volume of Central Bank swap operations may be compared to the volume of the monetary base in order to find out the necessary intervention to obtain a given depressing effect on the call rate. The level of $\mathrm{M} 0$ seems inadequate for such a comparison, not only because the economy experienced a re-monetization process, but because the call rate should be considered a marginal rate: the monthly increase in $\mathrm{M} 0$ is more appropriate. Central Bank interventions amounted (in average and corrected by length) to a $33.1 \%$ of the monthly increase in $\mathrm{M} 0$.

\section{SECOND PERIOD: FEBRUARY 1993-JUNE 1994}

In February 1993 the operating target was slightly modified: until then it had been the call rate, that is the interest rate within the financial system; hereafter it would be the market interest rates, with the goal of lowering the prevailing rate. At

\footnotetext{
${ }^{9}$ This time sequence call rate (explanatory variable) — swap rate (explained variable) is very important because it determines the direction of causation. A similar sequence says that the swap rate (explanatory variable), comes before the volume of operations (explained variable), not vice-versa.

${ }^{10}$ The Central Bank Charter mentions that their own rates should not imply a subsidy paid to financial institutions, a provision that may be incorrectly interpreted as implying that the swap rate in the case of interventions should always be higher than the call rate. If this were the case, there would be no swap operation since institutions would go to the overnight financial market. In general, the swap rate was slightly lower than the call rate or, when higher, used transitorily.
} 
that time, a second monetary policy instrument appeared on the stage: the (minimum) legal or statutory deposit reserve requirement for financial institutions.

The change of legal reserve coefficients is an indirect way to influence market nominal interest rates. In particular, a reduction of this coefficient implies a higher lending capacity and a lower financial cost for the financial system, creating a downward pressure on market interest rates. Real interest rates were in the sight of monetary authorities because a fall in nominal rates would lead to a fall in real rates. When real rates are high, economic activity is jeopardized and usually remains at a level lower than it could potentially achieve.

The call rate should drop because financial institutions in the short-term no longer need additional funds. In fact, since swap operations disappeared when reserve coefficients were reduced, the swap rate as a monetary instrument is not effective anymore. An alternative - albeit not exclusive - explanation of the re. duction of reserve requirements to obtain lower market rates is that the Central Bank, beginning in the last quarter of 1992, found itself increasingly unable to influence the call rate; hence it was compelled to take a more radical action.

Central Bank authorities quantitatively determine the legal reserve requirements. However, their discretion is limited by two restrictions: they should be used to regulate the quantity of money in, or the performance of, the financial system, and they should not be remunerated.

The coefficients established at the beginning of the convertibility program were higher than those normally required to financial institutions. They were so fixed because it would have been very dangerous to lower them in a time of rapid remonetization of the economy, like the one brought about by price stability.

Table 2 shows the conservative gradual reduction of reserve requirements that took place and the abrupt shift that occurred in February 1993. This drastic reduction was accompanied by some institutional changes devoted to consolidating the financial system; they included the elimination of special savings deposits accounts, a 30 day minimum term for time deposits, the unification of reserve requirements for demand and saving deposits, and a similar unification for domestic and foreign deposits. Moreover, according to government authorities, this last measure meant an additional step toward a complete dollarization of the financial system, where pesos and dollars would be perfect substitutes. 
Table 2: (Minima) Legal Reserve Requirements (\% of deposits)

\begin{tabular}{lccccc}
\hline $\begin{array}{l}\text { Type of } \\
\text { Deposit }\end{array}$ & 1991.5 & 1992.4 & $\begin{array}{c}\text { Date (end of month) } \\
1992.10\end{array}$ & 1993.2 & 1993.8 \\
\hline I. Domestic currency: & 80 & 77 & 71 & & 43 \\
Demand & 30 & 26 & 26 & 40 & 43 \\
Savings (common) & 5 & 3 & 3 & 40 & 3 \\
Savings (special) & 5 & 3 & 3 & 40 & 43 \\
Time (30-90 days) & & & & 40 & 43 \\
\hline II. Foreign currency: & & & 5 & 0 & 3 \\
$\quad$ Demand & 5 & 5 & &
\end{tabular}

In mid-August 1993 the Central Bank appeared to have realized that the February reduction of reserve requirements implied a liquidity of the financial system higher than that compatible with price stability; therefore, it decided a small increase in the requirements.

The overall reduction in reserve requirements created immediately an aggregate excess reserve in the financial system. This is shown in figure $2^{11}$. In turn, this increase in excess reserves had two related consequences. The first one was, as has been already said, to relieve the Central Bank of carrying out swap operations. During this period, there were only one important intervention in July 1993 and two small ones in April-May 1994 (see table 2 above), and at those times the call rate was at low levels.

Figure 2: Excess Reserves \& Interest Rates

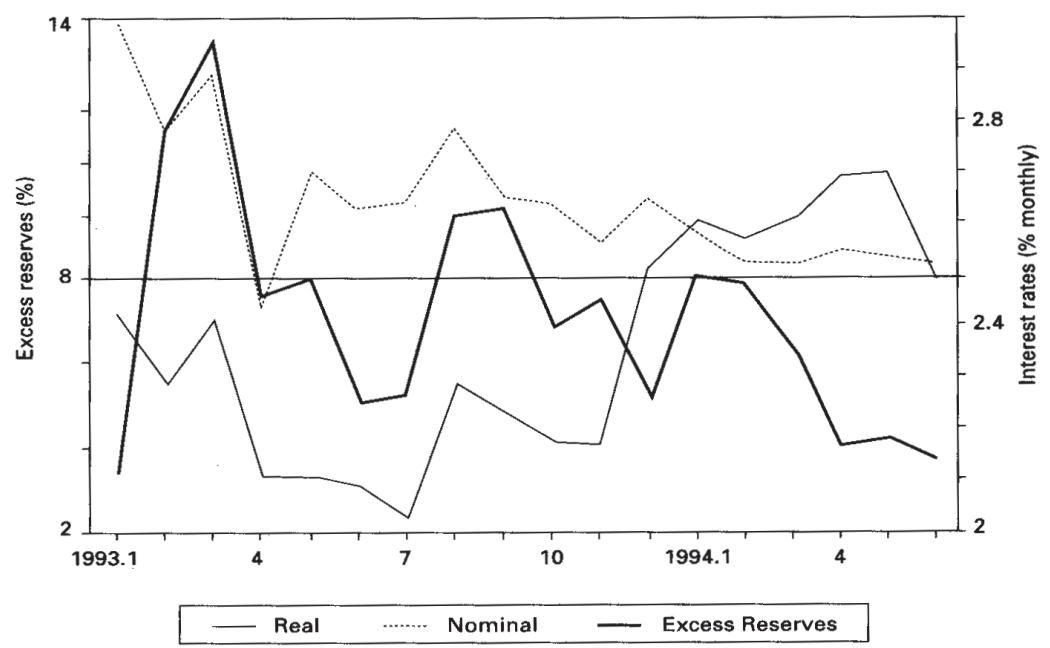

${ }^{11}$ There is an overestimation of the excess reserves since the Central Bank decided that the (minimum) legal reserve should be deposited in its vaults. The operating reserve should be increased consequently. 
The second consequence, the downward pressure on interest rates, was only small and temporary (3-4 months). Later, while the nominal rate remained quite constant (NIR \$ in figure 2), the real rate (RIR\$) went up as a consequence of international interest rate increases and stable domestic prices. Domestic real interest rates proved to be related mostly to foreign variables — including country risk and not to domestic monetary conditions. Therefore, the elasticity of interest rates to monetary policies turned out to be very small. Given the underlying conditions, this might have been a consequence of the segmentation of the financial markets between pesos and dollars (Arnaudo, 1993).

There was also a large disparity among interest rates applicable to operations denominated in pesos and dollars. The monetary authorities thought that a decrease and unification of the reserve requirements for deposits in both currencies would lead to a gradual convergence of the interest rates in pesos to those in dollars, something which would work in a context of free movement of capital. However, such a convergence was not achieved.

\section{THIRD PERIOD: JULY-NOVEMBER 1994}

From figure 1 , it is noticed that monetary aggregates denominated in pesos, which had increased persistently since the Convertibility Plan, gradually reached a ceiling by the time of this period. In other words, the re-monetization period, a permanent shift in the demand for monetary assets, had arrived to an end. Thus, it would be expected that the monetary base in the future would be driven to a large extent by the demand, well beyond the discretion of the monetary authorities in governing the supply.

As the monetary policy became more endogenous, the fiscal policy - summarized by the budget surplus/deficit - was the instrument in the hands of government authorities to cope with the disturbances that might arise in the economy. The general rule to have surpluses during economic expansions and deficits during recessions should be extended to allow for short-term shocks, in particular, budget transitory deficits. The Treasury should then have short-lived idle cash balances in the case of surpluses, and easy access to borrow from the financial system in the case of deficits.

However, when this second alternative was not available, a way to finance transitory budget deficits was to go to an indirect monetary instrument, the already mentioned swap operations, but with a peculiar feature. In this case the Central Bank provided funds to a state national bank (Banco de la Nación Argentina), which in turn would lend those funds to the government. Once the Treasury problems were cleared, the government debt would be paid back, so the state bank would be able to cancel the swap operation with the Central Bank.

This was the main characteristic of the brief third period of monetary policy. The kind of swap operation during this period differs from the one carried out in 
the first period because the call rate was completely irrelevant (it either increased, decreased or remained stable).

Table 3: Length of Central Bank Intervention and Non-intervention Periods, Call and Swap Interest Rates, and Amount of Swap Operations (simple averages)

\begin{tabular}{|c|c|c|c|c|}
\hline \multirow[b]{2}{*}{ Intervention } & \multirow{2}{*}{$\begin{array}{l}\text { Length } \\
\text { (days) } \\
\text { (1) }\end{array}$} & \multicolumn{2}{|c|}{$\begin{array}{l}\text { Interest Rates } \\
\text { ( 0/0, annual) }\end{array}$} & \multirow{2}{*}{$\begin{array}{c}\text { Amount } \\
\text { (average per day) } \\
\text { (million \$) } \\
\text { (4) }\end{array}$} \\
\hline & & $\begin{array}{l}\text { Call } \\
\text { (2) }\end{array}$ & $\begin{array}{l}\text { Swap } \\
\text { (3) }\end{array}$ & \\
\hline \multicolumn{5}{|l|}{ No } \\
\hline AprikJune & 12.0 & 7.3 & & \\
\hline July-November & 12.7 & 6.4 & & \\
\hline \multicolumn{5}{|l|}{ Yes } \\
\hline April-June & 17.5 & 8.9 & 9.2 & 18.6 \\
\hline July-November & 17.3 & 7.9 & 9.3 & 160.9 \\
\hline
\end{tabular}

According to table 3, the volume of swap operations was very large, many times the magnitude observed in the past. The transitory needs of the Treasury were substantial in relation to a practically stable monetary base. However, it is necessary to note the impossibility of disentangling from available official information the amount of swap operations "carried out normally with the financial system" from those "Treasury determined". Assuming that the whole volume of swap operations was due to the needs of the Treasury - a hypothesis based on qualitative grounds -, a comparison of the figures for the period April-June with those of the period July-November gives a rough indication of the magnitude of these operations.

\section{FOURTH PERIOD: DECEMBER 1994-MAY 1995}

In December 1994, the Mexican economic authorities performed an abrupt devaluation of the domestic currency ${ }^{12}$, an event which instantaneously had effects on other Latin American countries, particularly on the Argentine economy (Arnaudo, 1996; Broda \& Secco, 1996). At that time, the credibility of the Argentine stabilization program (the Convertibility Plan) based on a fixed exchange rate dropped to its lowest level, giving rise to a widespread financial crisis. Furthermore, it coincided in the domestic flank with substantial budget deficits at the national level which started in the second quarter of 1994, and with a time when the Central Bank was restricted from executing discretionary monetary policies.

The financial crisis evolved into two successive sub-periods. During the first one, which lasted a few weeks, executives of foreign firms and investors in the segment of peso denominated time deposits rapidly reacted; somebody has called it

12 The Mexican financial crisis is a phenomenon widely discussed to be repeated here. 
the CEO crisis. Anticipating a devaluation of the currency - as it happened in Mexico -, CEOs converted demand deposits into foreign currency (dollar) to avoid exchange rate losses; they were probably so instructed by their parent companies. Likewise, investors in peso denominated time deposits, who were attracted by the spread between international and domestic interest rates, did the same as soon as the deposits matured.

During the second sub-period, from mid-February onwards, local depositors in foreign currency $(42.7 \%$ of total deposits in the financial system took the form of time deposits in dollars; only $20 \%$ time deposits in pesos, November figures) became wholly aware of the financial crisis and therefore started to withdraw their deposits. This can be seen in table 4 .

Table 4: Variation of Deposits during the Different Periods of the Crisis (in \% of the previous level)

\begin{tabular}{ccccc}
\hline & \multicolumn{2}{c}{ First Periodod } & \multicolumn{2}{c}{ Second Period } \\
Type of & $\begin{array}{c}\text { December 20- } \\
\text { January 4 }\end{array}$ & $\begin{array}{c}\text { January 4- } \\
\text { January 31 }\end{array}$ & $\begin{array}{c}\text { January 31- } \\
\text { February 22 }\end{array}$ & $\begin{array}{c}\text { February } \\
\text { 22 April 10 }\end{array}$ \\
\hline$\$$ & & & & \\
Demand & -4.1 & -1.9 & -0.2 & 04 \\
Saving & 0.0 & 5.1 & -15.0 & -6.7 \\
Time & -13.4 & -12.3 & 0.3 & -13.4 \\
us & 1.5 & & & -12.0 \\
Saving & -0.5 & 1.0 & -2.3 & -14.1 \\
Time & & & -1.6 & \\
\hline
\end{tabular}

Disregarding the real sector, the financial crisis showed two different outcomes: a loss of international reserves and a decrease in bank deposits. The aim of the monetary authorities was not only to halt these two consequences, but essentially to restore within the public and foreign investors the confidence on the main component of the stabilization plan, that is the fixed exchange rate. For the same purpose the authorities reiterated the soundness of the fiscal policy and the strength of the financial system.

The drop in international reserves was substantial as depicted in table 5 , and was associated with the loss of deposits occurred in the first period of the crisis. As mentioned, time deposits in pesos were converted into local and later into foreign currency (compare the figures of tables 4 and 5). The loss of deposits was widespread among individual banks, but only a small number of banks and financial institutions were initially closed ${ }^{13}$.

\footnotetext{
13 In 1995, due to the effects of the Mexican crisis on the Argentine economy, the financial sector underwent a very large re-structuration involving more than forty financial institutions. The operation led to a concentration of the system, but it seems that it did not have effects on its solvency (Arnaudo, 1997).
} 
Table 5: Variations of the International Monetary Aggregates and Policy Variables during the Crisis (absolute values, in million \$/us; in parentheses, \% with respect to November 1994)

\begin{tabular}{lcccccc}
\hline \multicolumn{1}{c}{ Type } & December & January & February & March & April & May \\
\hline International Reserves & & & & & & \\
Central Bank & 1726 & -512 & -1227 & -4107 & -2803 & -3405 \\
& $(12.1)$ & $(-3.6)$ & $(-8.6)$ & $(-287)$ & $(-196)$ & $(-238)$ \\
Financial Institutions & 661 & 430 & -1474 & -924 & -1595 & -976 \\
& $(10.9)$ & $(7.1)$ & $(-24.3)$ & $(-152)$ & $(-263)$ & $(-161)$ \\
Legal Reserves & & & & & & \\
\$ & 191 & -1232 & -1578 & -1539 & -1374 & -1335 \\
& $(3.6)$ & $(-22.9)$ & $(-29.4)$ & $(-287)$ & $(-25.6)$ & $(-249)$ \\
us & -216 & -731 & -776 & 706 & -788 & -858 \\
& $(-92)$ & $(-31.1)$ & $(-31.8)$ & $(-30.1)$ & $(-33.5)$ & $(-365)$ \\
Central Bank Discounts & 63 & 207 & 571 & 1528 & 1755 & 1813 \\
\hline
\end{tabular}

The reaction of the monetary authorities increased as the crisis developed, and as the measures implemented were not sufficient for solving the problems. In December, the Central Bank reduced the legal reserve requirements ${ }^{14}$ in order to help banks to honor the unusual withdrawal of deposits; it also maintained the access (although limited) to swap operations with the financial system. Later, it bolstered a "security network" consisting of transitory loans to those banks particularly affected by the deposit flight; the funds were provided by a group of five major banks, including the official Banco de la Nación Argentina.

Whether this security network was unsuccessful or had limited funds for its purpose, it proved to be insufficient for the needs of the banks. Therefore, the monetary authorities had to implement with the same purpose an official fund administered by Banco de la Nación Argentina and funded with cash provided by those banks having liquid assets in excess of the legal requirement. It is important to note that at that time the Central Bank was unable to employ its own funds to help the financial system in such an extraordinary situation.

Since the new facility was also insufficient, a more radical therapy turned to be necessary. In February, the Argentine economic authorities declared that the government would discuss an arrangement with the International Monetary Fund, something which was concluded in March with a stand-by credit facility. This facility implied that the expansive policies carried out in the recent past had to be reversed $^{15}$. Some analysts had argued that these policies were in fact the efficient

\footnotetext{
${ }^{14}$ Probably the Central Bank was very permissive with financial institutions regarding the requirement of legal reserves.

${ }^{15}$ Suffice to say that some taxes were increased, government expenditures reduced, public assets sold,
} 
instruments to restore the credibility on the Convertibility Plan, rather than specific policies aimed to the financial system itself.

In summary, the new macroeconomic policy was directed to obtain a seal of confidence among domestic and foreign agents. In spite of those global actions, the financial sector required individual measures anyway since it had not overcome its problems; on the contrary, it had to cope with the widespread flight of deposits during the second sub-period of the crisis.

Therefore, three actions were taken by the economic authorities. First, through an extraordinary order of the Executive branch, which was later endorsed by Congress, the Central Bank was entitled to be a lender of last resort in case of generalized crisis, albeit still restricted by the provisions of the Convertibility Law and the capital of the banks. Second, a limited, compulsory and costly (for the financial institutions) deposit guaranty scheme was created; its aim was to halt the flight of domestic assets toward more secure foreign ones. Third, two funds, devoted to help the acquisition of weak banks by other stronger ones, were created and implemented; these funds were mainly integrated with loans lent by international organizations. However, these funds were not used at that moment because the loans coming from them were related to the capital of the stronger (or bigger) institutions, which were reluctant to buy or merge with weaker (or smaller) ones.

\section{FIFTH PERIOD: JUNE 1955 ONWARDS}

The main characteristic of this period, which still persists nowadays, is the gradual transition to the path observed before the Mexican crisis (partially depicted in figure 3). Nevertheless, the special feature of widespread dollarization of the financial system (although not of the real sector) needs to be considered. This dollarization was praised as a way to have a solid financial system, less vulnerable to crisis. Deposits and loans denominated in dollars were very common in the near past, but it seems that the monetary authorities only progressively realized some ultimate consequences of a system of two equivalent and convertible currencies.

The traditional concept of monetary base, "consisting of the Central Bank notes in the hands of the public and in the tills of the banks [...] [which] provides the cash base on which the much larger superstructure of convertible deposits is erected" (Goodhart, 1987), had to be reformulated. The possibility that reserve requirements for deposits in pesos and dollars could be met with either currency removed any meaning to that concept. Monetary liabilities and financial liabilities have substituted the concept of monetary base in Central Bank statements; however, their precise definitions, and particularly their significance, has not been assessed yet.

To a large extent, as the financial variables (mainly deposits and loans) little

and so forth. 
by little regained their previous levels, the soundness and solvency of the financial system was the main goal of the policies carried out by the monetary authorities. Although several policies were enacted in the previous months, they became more important and closely supervised after the crisis. These policies can be grouped in three categories, according to the time they were in operation.

First, the financial institutions were required to have a minimum capital/assets ratio, as it has been recommended by the Basle rules. The original rules were written so as to require financial institutions to be solvent and to have own liquid funds in the event of market pressures or financial crises. The ratios used in Argentina were higher than those of Basle, thus it is possible to consider them as more restrictive. However, these higher ratios could be explained by the fact that Argentine financial institutions have a great deal of real estate assets, hard to be transformed rapidly in liquid funds.

In addition, financial institutions have been recently required to issue bonds in international capital markets, amounting to not less that $2 \%$ of their deposits. These bonds would not have the guaranty granted to deposits. The hypothesis would be that the monetary authorities seek an extra source of liquidity to make the system less fragile, or that they expect a market valuation of the health of individual banks; however, the latter seems very unlikely.

Second, deposit requirements were initially constituted in either domestic or foreign currency, and later (August 1995) eliminated entirely. In their place, liquidity requirements were imposed in proportion to the amount of deposits and other items. These requirements have three characteristics: they were uniform (applied to every kind of domestic or foreign liability), remunerated, and susceptible of being placed at a bank in New York. In the beginning, these requirements were integrated with Central Bank deposits and government securities ${ }^{16}$; later they were gradually deposited in New York in order to avoid the payment of interest by the government or the Central Bank (figure 3).

Third, to increase the potential amount of foreign reserves, the Central Bank accorded with some major international banks a $\$ 6.2$ bn stand-by credit facility, by which the Bank has the option to obtain loans up to that amount in the case of a financial crisis. The loans would have a maturity of up to five years and would be guaranteed by government bonds; the commitment requires the payment of a 0.3 $\%$ annual fee by the Central Bank.

All these measures were intended to enhance the liquidity and solvency of the Argentine financial system. However, one may be suspicious about its efficacy; the risk of a financial crisis can not be insured, it is an uncertain event. The health of the financial system ultimately can only be maintained by sound macroeconomic policies.

${ }^{16}$ By the way, the Central Bank net income-expense from swap operations is unknown. 
Figure 3: Bank Liquidity

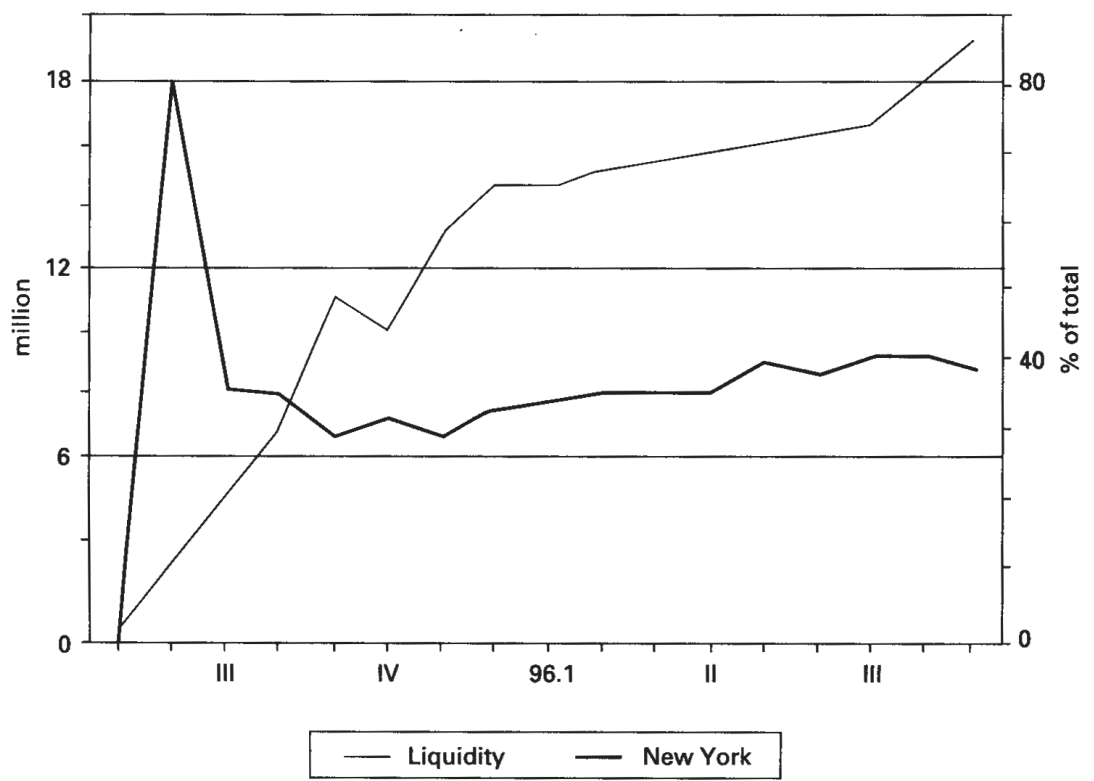

\section{A SUMMING UP}

The Argentine experience shows that the convertibility of the currency limits to a large extent the discretion of monetary policy. Notwithstanding, monetary policies are feasible to some degree as they pursue different objectives; of course, it might happen that these objectives are not always fulfilled.

The conclusions from the Argentine recent experience may be summarized in the following table:

\begin{tabular}{|c|c|c|c|c|}
\hline Period & Goal & Operating Target & Instrument & Outcome \\
\hline $1 s t$ & Interest rate stability & Call interest operation & Swap & Success \\
\hline 2nd & Lowering interest rates & Market interest rates & Reserve requirement & Mixed \\
\hline 3rd & Fiscal policy substitution & Transitory budget deficits & Swap operation & $?$ \\
\hline 4th & Stop financial crisis & Help system & Many & Success \\
\hline 5th & Financial sector solvency & Liquidity/solvency & Liquidity/solvency ratios & Mixed \\
\hline
\end{tabular}




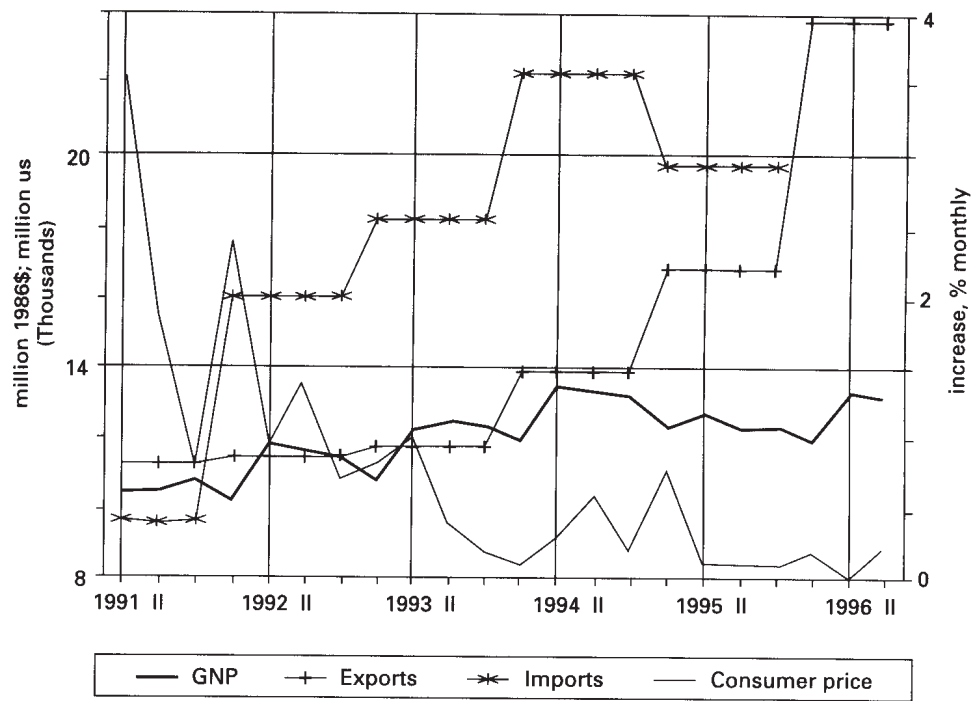

\section{REFERENCES}

ARNAUDO, Aldo A. (1993) “Convertibilidad y Tasas de Interés”, Actualidad Económica 3, 17, nov. ( 1994) “La Política Monetaria Argentina desde la Convertibilidad”, Monetaria 17, 4, oct/dec. (1996) "La Crisis Mexicana y el Sistema Financiero Argentino", in Rodríguez Prada, Gonzalo (ed.). La Macroeconomía de los Mercados Emergentes. Madrid, Ediciones de la Universidad de Alcalá.

(1997) La Reetructuración de los Bancos Privados Argentinos de 1995 (mimeo).

BATTEN, Dallas S. et al. (1990) "The Conduct of Monetary Policy in the Major Industrial Countries. Instruments and Operating Procedures". IMF, Occasional Paper 70.

BENNETT, Adam G. G. (1994) “Currency Boards: Issues and Experiences”, in BALIÑO, Tomás J. T. \& COTTARELLI, Carlo (ed.). Frameworks for Monetary Stability. Washington, IMF.

BERNANKE, Ben \& BLINDER, Alan (1992) “The Federal Fund Rate and the Channels of Monetary Transmission”, American Economic Review 82, 4, sep.

BRODA, Miguel A. \& SECCO, Luís (1996) "Caja de Conversión Pura o un Banco Central con Límites Estrictos?. Las Ventajas de la Flexibilidad durante la Crisis del Primer Trimestre de 1995 Anales de la 3 la. Reunión Anual de la Asociación Argentina de Economía Política, tomo 2.

BRUNNER, Karl (ed.) (1969) Targets and Indicators ofMonetary Policy. San Francisco, Chandler Publishing.

FRIEDMAN, Benjamin M. (1975) “Targets, Instruments, and Indicators of Monetary Policy”. Journal of Monetary Economics 1, 4, oct.

GOODHART, Charles (1987) "Monetary Base”, The New Palgrave.

KRUGMAN, Paul M. (1979) "A Model of Balance-of-Payments Crisis”. Journal of Money, Credit and Banking 11, 3, aug. 